\title{
Proses Keperawatan dalam Asuhan Keperawatan
}

\author{
Eka Rosliani Nasution \\ ekaroslianinasution1303@gmail.com
}

\begin{abstract}
Abstrak
Asuhan keperawatan adalah suatu pendekatan untuk pemecahan masalah pada pasien dengan memberikan pelayanan keperawatan. Sejauh ini perawat tidak sepenuhnya melakukan asuhan keperawatan sesuai dengan SOP. Mutu asuhan keperawatan sangat dipengaruhi oleh kualitas pelayanan kesehatan dan bahkan sering menjadi salah satu faktor penentu citra institusi palayanan di mata masyarakat. Untuk menilai kualitas pelayanan keperawatan diperlukan adanya standar praktik keperawatan yang merupakan pedoman bagi perawat dalam melaksanakan asuhan keperawatan yang diwujudkan dalam bentuk proses keperawatan baik dari pengkajian sampai evaluasi. Pengetahuan merupakan salah satu faktor yang erat kaitanya dengan efektifitas penerapan asuhan keperawatan. Manajemen asuhan keperawatan merupakan suatu proses keperawatan yang menggunakan konsep manajemen secara umum didalamnya seperti perencanaan, pengorganisasian, pengarahan dan pengendalian atau evaluasi. Peningkatan mutu pelayanan adalah derajat memberikan pelayanan secara efisien dan efektif sesuai dengan standar profesi, standar pelayanan yang dilaksanakan secara menyeluruh sesuai dengan kebutuhan pasien, memanfaatkan teknologi tepat guna dan hasil penelitian dalam pengembangan pelayanan kesehatan/ keperawatan sehingga tercapai derajat kesehatan yang optimal.
\end{abstract}

\section{Latar Belakang}

Pembangunan kesehatan bertujuan meningkatkan kemampuan hidup sehat bagi setiap masyarakat agar dapat mewujudkan derajat kesehatan masyarakat yang optimal sebagai salah satu unsur kesejahteraan umum dari tujuan nasional (Depkes RI, 1990). Tujuan pembangunan bidang kesehatan dapat ditempuh melalui pelayanan kesehatan dasar Puskesmas (Depkes RI, 1995). Dalam rangka penyelenggaraan pelayanan kesehatan, kegiatan perawatan mempunyai peranan dalam menentukan keberhasilan kesehatan secara keseluruhan. T enaga kesehatan yang selama 24 jam harus berada disisi pasien adalah perawat (Depkes RI, 1993).

Mutu asuhan keperawatan sangat dipengaruhi oleh kualitas pelayanan kesehatan dan bahkan sering menjadi salah satu faktor penentu citra institusi pelayanan di mata masyarakat. Dalam rangka mempertahankan dan meningkatkan kualitas asuhan keperawatan diperlukan alat ukur untuk menilai standar asuhan keperawatan yang terdiri dari tiga bagian yaitu instrumen A tentang standar proses keperawatan; instrumen B tentang standar persepsi dan kepuasan pasien; dan instrumen C tentang standar prosedur keperawatan. Standar asuhan keperawatan berfungsi sebagai pedoman maupun tolak ukur dalam pelaksanaan praktek keperawatan agar sesuai dengan nilai-nilai profesional, etika dan tanggung jawab. (Anwar, 1980).

Peningkatan mutu keperawatan dapat diperoleh jika perawat mampu melaksanakan asuhan 
keperawatan sesuai standar, yaitu mulai dari pengkajian sampai dengan evaluasi lengkap dengan dokumentasi. Permasalahan yang sering muncul dan dihadapi di Indonesia dalam pelaksanaan asuhan keperawatan adalah banyak perawat yang belum melakukan pelayanan keperawatan sesuai standar asuhan keperawatan dan tidak disertai dokumentasi yang lengkap (Hariyati, 2009).

Dokumentasi asuhan keperawatan merupakan persyaratan legal dalam setiap lingkungan pelayanan kesehatan, dimana dengan banyaknya gugatan dan sorotan malpraktik agresif dalam masyarakat, semua aspek rekam medis penting untuk pencatatan legal (Zaidin Ali, 2009 dalam Olfah, Y. dan Ghofur, A., 2016).

Dokumentasi merupakan suatu dokumen yang berisi data lengkap, nyata, dan tercatat bukan hanya tentang tingkat kesakitan pasien tetapi juga jenis dan kualitas pelayanan kesehatan yang di berikan (Niken,P.S 2017). Menurut Perry \& potter (2005), tujuan pendokumentasian yaitu sebagai alat komunikasi tim kesehanan untuk menjelaskan perawatan klien termasuk perawatan individual, edukasi klien dan penggunaan rujukan untuk rencana pemulangan (Niken,P.S 2017).

Sistem model asuhan keperawatan professional (MAKP) adalah suatu kerangka kerja yang mendefinisikan empat unsur yakni standar, proses keperawatan, pendidikan keperawatan, sistem MAKP. Perawat profesional dalam memberikan pelayanan keperawatan di masa depan adalah harus dapat berkomunikasi secara lengkap, adekuat dan cepat (Nursalam, 2012). Pelayanan keperawatan akan lebih memuaskan tentunya dengan penerapan model asuhan keperawatan professional atau MAKP karena kepuasan pasien ditentukan salah satunya dengan pelayanan keperawatan yang optimal (Fisbach, 1991 dalam jurnal Nur Hidayah, 2014). Untuk menilai kualitas pelayanan keperawatan diperlukan adanya standar praktik keperawatan yang merupakan pedoman bagi perawat dalam melaksanakan asuhan keperawatan yang diwujudkan dalam bentuk proses keperawatan baik dari pengkajian sampai evaluasi (Nursalam, 2008).

Keperawatan adalah salah satu profesi pelaku pemberi pelayanan kesehatan, memiliki peranan penting dalam menentukan keberhasilan kesehatan secara keseluruhan. Pelayanan keperawatan merupakan pelayanan profesional sebagai bagian integral dari pelayanan kesehatan yang didasarkan ilmu dan kiat keperawatan (Nursalam, 2008). Tenaga perawat mempunyai kedudukan penting dalam menghasilkan kualitas pelayanan kesehatan dirumah sakit, karena pelayanan yang di berikannya berdasarkan pendekatan bio-psiko-sosial-spiritual merupakan pelayanan yang unik dan dilaksanakan selama 24 jam dan berkesinambungan, hal ini merupakan kelebihan tersendiri dibanding profesi kesehatan lainnya (DepKes RI, 2005). Mutu asuhan keperawatan sangat dipengaruhi oleh kualitas pelayanan kesehatan dan bahkan sering menjadi salah satu faktor penentu citra institusi palayanan di mata masyarakat. Untuk menilai kualitas pelayanan keperawatan diperlukan adanya standar praktik keperawatan yang merupakan pedoman bagi 
perawat dalam melaksanakan asuhan keperawatan yang diwujudkan dalam bentuk proses keperawatan baik dari pengkajian sampai evaluasi (Nursalam, 2008).

Dokumentasi asuhan keperawatan mencakup pernyataan dan pelaporan tentang pengkajian (pengumpulan data), diagnosis keperawatan, rencana tindakan keperawatan, tindakan dan evaluasi keperawatan.Dokumentasi yang efektif menjamin kesinambungan pelayanan, menghemat waktu, dan meminimalisasi resiko kesalahan (Potter \& Perry, 2009).Dokumentasi asuhan keperawatan yang baik dan berkualitas haruslah akurat, lengkap dan sesuai standar.Apabila asuhan keperawatan tidak didokumentasikan dengan akurat dan lengkap maka sulit untuk membuktikan bahwa asuhan keperawatan telah dilakukan dengan benar (Hidayat dalam Sari, 2012). Pendokumentasian asuhan keperawatan merupakan suatu proses yang harus dilaksanakan oleh perawat pelaksana sebagai bagian dari standar kerja yang telah ditetapkan (Nursalam, 2007).

Mutu asuhan keperawatan dapat tergambar dari dokumentasi proses keperawatan (Gillies, 1994). Dokumentasi dalam keperawatan memegang peranan penting terhadap segala macam tuntutan masyarakat yang semakin kritis dan mempengaruhi kesadaran masyarakat akan hakhaknya dari suatu unit kesehatan.

Pendokumentasian merupakan suatu kegiatan pencatatan, pelaporan atau merekam suatu kejadian serta aktivitas yang dilakukan dalam bentuk pemberian pelayanan yang dianggap penting dan berharga (Dalami, 2011). Pendokumentasian yang tidak dilakukan dengan lengkap dapat menurunkan mutu pelayanan keperawatan karena tidak dapat mengidentifikasi sejauh mana tingkat keberhasilan asuhan keperawatan yang telah diberikan, dalam aspek legal perawat tidak mempunyai bukti tertulis jika klien menuntut ketidakpuasan akan pelayanan keperawatan (Nursalam, 2008; Iyer, 2001).

Dokumentasi asuhan keperawatan menggunakan pendekatan proses keperawatan yang terdiri dari pengkajian, perumusan diagnosa, perencanaan, pelaksanaan, dan evaluasi sebagai metode ilmiah penyelesaian masalah keperawatan pada pasien untuk meningkatkan outcome pasien (Aziz, 2002). Ciri dokumentasi asuhan keperawatan yang baik adalah berdasarkan fakta (factual basis), akurat (accuracy), lengkap (completeness), ringkas (conciseness), terorganisir (organization), waktu yang tepat (time liness), dan bersifat mudah dibaca (legability) (Potter \& Perry; 2009). Prinsip-prinsip pendokumentasian direvisi menjadi tiga bentuk standar dokumentasi yaitu communication, accountability, dan safety (ANA, 2010).

Menurut Gibson dan Ivancevich terdapat tiga faktor yang mempengaruhi kinerja, yaitu faktor individu, faktor organisasi, dan faktor psikologi (Gibson, 2001). Faktor psikologi salah satunya motivasi, merupakan interaksi seseorang dengan situasi tertentu yang dihadapinya dan memberikan dorongan penggerak (disadari maupun tidak disadari) melalui suatu proses untuk 
mencapai tujuan tertentu yang diinginkan atau menjahui situasi yang tidak menyenangkan (Suarli \& Yayan, 2008).

Faktor organisasi, supervisi adalah pengamatan secara langsung dan berkala oleh atasan terhadap pekerjaan yang dilakukan bawahan, apabila ditemukan masalah segera diberikan bantuan yang bersifat langsung guna mengatasinya (Suarli \& Yayan, 2008).

Hal ini yang melatarbelakangi penulis untuk melakukan penelitian mengenai hubungan karakteristik perawat, motivasi, dan supervisi dengan kualitas dokumentasi proses asuhan keperawatan. Tujuan penelitian ini adalah untuk mengetahui hubungan antara karakteristik perawat, motivasi, dan supervisi dengan kualitas dokumentasi asuhan keperawatan.

Asuhan keperawatan adalah suatu pendekatan untuk pemecahan masalah yang memampukan perawat untuk mengatur dan memberikan asuhan keperawatan. Standar asuhan yang tercantum dalam Standar Praktik Klinis Keperawatan terdiri dari lima fase asuhan keperawatan: 1) Pengkajian; 2) Diagnosa; 3) Perencanaan; 4) Implementasi; dan 5) Evaluasi. Salah satu manfaat dari penerapan asuhan keperawatan yang baik adalah meningkatkan mutu dan kualitas pelayanan dalam bidang keperawatan (Kozier, 2010).

Menurut Sumijatun (2010, p.88) permasalahan pelayanan keperawatan di negara Indonesia adalah banyaknya perawat yang belum melakukan asuhan keperawatan sesuai dengan standar. Di sebagian besar tatanan pelayanan keperawatan, masih terbatas melakukan kegiatan-kegiatan yang belum memenuhi kaedah asuhan keperawatan secara profesional yang bertanggung gugat.

\section{Metode}

Penulisan ini menggunakan metode penelitian kualitatif, yaitu suatu penelitian yang pada dasarnya menggunakan pendekatan deduktif-induktif. Pendekatan ini berangkat dari suatu kerangka teori, gagasan para ahli, maupun pemahaman peneliti berdasarkan pengalamannya yang kemudian dikembangkan menjadi permasalahan-permasalahan beserta pemecahannya yang diajukan untuk memperoleh pembenaran (verifikasi) dalam bentuk dukungan data empiris di laporan. Penelitian kualitatif ini menggunakan desain penelitian studi kasus. Studi kasus dilakukan dengan cara meneliti suatu permasalahan melalui suatu kasus yang terdiri dari unit tunggal. Pembatasan masalah dalam penelitian kualitatif disebut fokus penelitian. Fokus dalam penelitian ini adalah "Penerapan Proses Keperawatan di Layanan Kesehatan". Singkatnya, metode penelitian kualitatif adalah penelitian tentang riset yang bersifat deskriptif dan menggunakan analisis. Kemudian diinterpretasikan dengan memanfaatkan teori yang ada sebagai bahan pendukung. Melakukan observasi yang didasarkan atas literatur penelitian. Lalu dijelaskan secara deskriptif berdasarkan literatur tersebut. Nantinya akan disesuaikan dengan judul jurnal ini yaitu "Penerapan Proses Keperawatan di Layanan Kesehatan”. Pengumpulan data dalam pengkajian ini menggunakan jurnal 
dan buku. Jurnal dan buku yang digunakan dalam pengkajian ini untuk menunjang kevalidan data yang telah diperoleh. Setelah itu akan dikaji sesuai dengan bahan teori yang sudah ada untuk menghasilkan penelitian yang berkualitas.

\section{Hasil}

Pelatihan asuhan keperawatan dipengaruhi oleh beberapa faktor (Soeprijadi, 2006) :

a) a. Faktor pelatih, dengan menggunakan pelatih yang profesional

b) Faktor peserta, pelatihan yang mempunyai rasa kebersamaan tinggi dilihat dari dinamika kelompok yang sangat mendukung ke arah proses belajar mengajar

c) Faktor metode pelatihan, metode yang tepat akan menimbulkan kegairahan belajar para peserta.

d) Faktor materi pelatihan yang disusun dengan baik akan menimbulkan ketekunan dari peserta pelatihan.

\section{Pembahasan}

Menurut Nursalam (2008) hakikat dokumentasi asuhan keperawatan adalah terciptanya kegiatan-kegiatan keperawatan yang menjamin tumbuhnya pandangan, sikap, cara berpikir, dan bertindak profesional pada setiap perawat. Pendekatan yang sistematis dan logis dengan landasan ilmiah yang benar, serta melalui dokumentasi proses keperawatan, semua kegiatan dalam proses keperawatan dapat ditampilkan kembali sehingga dapat diteliti ulang untuk dikembangkan atau diperbaiki (Nursalam, 2008).

\section{Asuhan Keperawatan}

\section{Definisi Asuhan Keperawatan}

Asuhan keperawatan merupakan proses atau rangkaian kegiatan praktik keperawatan langsung pada klien di berbagai tatanan pelayanan kesehatan. Asuhan keperawatan dilaksanakan berdasarkan kaidah-kaidah keperawatan sebagai profesi yang berdasarkan ilmu dan kiat keperawatan, bersifat humanistik, dan berdasarkan kebutuhan objektif klien untuk mengatasi masalah yang dihadapi klien. Asuhan keperawatan merupakan inti pelayanan/praktik keperawatan (Ali, 2002).

\section{Tujuan dan Manfaat Proses Keperawatan}

Tujuan penerapan proses keperawatan bagi klien, antara lain:

a) Mempertahankan kesehatan klien,

b) Mencegah sakit yang lebih parah/ penyebaran penyakit/ komplikasi akibat penyakit,

c) Membantu pemulihan kondisi klien setelah sakit, 
d) Mengembalikan fungsi maksimal tubuh, dan membantu klien terminal untuk meninggal dengan tenang.

\section{Teori yang Mendasari Proses Keperawatan}

a. Teori sistem Teori sistem merupakan suatu kerangka kerja yang berhubungan dengan keseluruhan aspek sosial, manusia, struktur, masalah-masalah organisasi, serta perubahan hubungan internal dan lingkungan di sekitarnya. Sistem tersebut terdiri atas tujuan, proses, dan isi. Tujuan adalah sesuatu yang harus dilaksanakan. Proses berfungsi dalam memenuhi tujuan yang hendak dicapai, dan isi terdiri atas bagian yang membentuk suatu sistem. Keterkaitan antara teori sistem dengan proses keperawatan dapat dijelaskan melalui masukan (input), hasil (output), dan umpan balik (feedback) (Nursalam, 2008).

b. Teori kebutuhan manusia Teori ini memandang bahwa manusia sebagai bagian integral yang berintegrasi satu sama lain dalam motivasinya untuk memenuhi kebutuhan dasar (fisiologis, keamanan, kasih sayang, harga diri, dan aktualisasi diri). Setiap kebutuhan manusia merupakan suatu "tegangan internal" sebagai akibat dari perubahan setiap komponen sistem. Tegangan tersebut dimanifestasikan dalam perilaku untuk memenuhi kebutuhan atau tujuan sampai tingkat kepuasan klien (Nursalam, 2008).

c. Teori persepsi Terjadinya perubahan dalam pemenuhan kebutuhan dasar manusia sangat dipengaruhi oleh persepsi individu. Setiap manusia selalu berubah kebutuhan dan kepuasannya berdasarkan perubahan perilaku yang sangat unik. Akibatnya, setiap perubahan terjadi persepsinya akan selalu berbeda antara individu yang satu dengan individu yang lain (Nursalam, 2008). d. Teori informasi dan komunikasi .Tujuan asuhan keperawatan adalah untuk meengidentifikasi masalah klien. Proses keperawatan sebagai salah satu pendekatan utama dalam pemberian asuhan keperawatan pada dasarnya merupakan suatu proses pengambilan keputusan dan penyelesaian masalah. Setelah penerapan proses keperawatan, perawat dituntut mempunyai pengetahuan tentang konsep dan teori sebagai dasar dalam mengartikan data yang diperoleh serta dapat menjalin komunikasi yang efektif (Nursalam, 2008). Teori pengambilan keputusan dan penyelesaian masalah Setiap tindakan yang dilakukan secara rasional oleh seseorang selalu melibatkan keputusan atau pilihan. Setiap pengambilan keputusan dan penyelesaian masalah menuntut seseorang untuk dapat menerima hal baru, perbedaan, dan aspek-aspek yang lebih kompleks dari lingkungan yang sudah ada (Nursalam, 2008).

\section{Metode Asuhan Keperawatan}

Terdapat beberapa metode pemberian asuhan keperawatan, yaitu metode kasus, metode fungsional, metode Tim, dan metode keperawatan primer (Gillies, 1989 dalam Sitorus, 2006) : 
a) Metode kasus Metode kasus merupakan metode pemberian asuhan keperawatan yang pertama kali digunakan. Metode ini menggunakan satu perawat yang memberikan asuhan keperawatan kepada seorang klien secara total dalam satu periode dinas. Jumlah klien yang dirawat oleh satu perawat tergantung pada kemampuan perawat tersebut dan kompleksnya kebutuhan klien (Sitorus, 2006).

b) Metode fungsional Pemberian asuhan keperawatan pada metode fungsional ditekankan pada penyelesaian tugas dan prosedur. Setiap perawat diberi satu atau beberapa tugas untuk dilaksanakan kepada semua klien di suatu ruangan. Komunikasi antar perawat sangat terbatas sehingga tidak ada satu perawat yang mengetahui tentang satu klien secara komprehensif kecuali mungkin kepala ruangan. Keterbatasan itu sering menyebabkan klien merasa kurang puas terhadap layanan atau asuhan yang diberikan. Kepala ruangan menentukan tugas setiap perawat dalam suatu ruangan. Perawat akan melaporkan tugas yang dikerjakannnya kepada kepala ruangan dan kepala ruangan tersebut bertanggung jawab dalam membuat laporan klien (Sitorus, 2006).

c) Metode tim Metode tim merupakan metode pemberian asuhan keperawatan, yaitu seorang perawat professional memimpin sekelompok tenaga keperawatan dalam memberikan asuhan keperawatan pada sekelompok klien melalui upaya kooperatif dan kolaboratif (Douglas, 1992, dalam Sitorus, 2006).

d) Metode keperawatan primer Menurut Gillies (1989, dalam Sitorus, 2006) keperawatan primer merupakan suatu metode pemberian asuhan keperawatan, dimana terdapat hubungan yang dekat dan berkesinambungan antara klien dan seorang perawat tertentu yang bertanggungjawab dalam perencanaan, pemberian, dan koordinasi asuhan keperawatan klien, selama klien dirawat. Perawat yang bertanggungjawab terhadap pemberian asuhan keperawatan disebut perawat primer (primary nurse) disingkat dengan PP. Perawat bertanggungjawab untuk mengadakan komunikasi dan koordinasi dan membuat rencana pulang klien jika diperlukan (Sitorus, 2006).

\section{Komponen Proses Keperawatan}

a) Pengkajian merupakan dasar utama atau langkah awal dari proses keperawatan secara keseluruhan (Gaffar, 1999). Pengkajian harus dilakukan secara komprehensif terkait dengan asfek biologis, psikologis, sosial, maupun spiritual klien. Tujuan pengkajian adalah untuk mengumpulkan informasi dan membuat data dasar klien (Asmadi, 2008). Data akan dikumpulkan dan dianalisa untuk menentukan diagnosa keperawatan (Gaffar, 1999). Metode utama yang dapat digunakan dalam pengumpulan data adalah wawancara, observasi, dan pemeriksaan fisik serta diagnostik (Asmadi, 2008). 
b) Diagnosis keperawatan adalah pernyataan yang menguraikan respon aktual atau potensial klien terhadap masalah kesehatan yang perawat mempunyai izin dan berkompeten untuk mengatasinya. Respon aktual dan potensial klien didapatkan dari data dasar pengkajian, tinjauan literatur yang berkaitan, catatan medis klien masa lalu, dan konsultasi dengan profesional lain, yang dikumpulkan selama pengkajian (Potter \& Perry, 2005). Pernyataan diagnosis keperawatan harus jelas, singkat, dan lugas terkait masalah kesehatan klien berikut penyebabnya yang dapat diatasi melalui tindakan keperawatan (Asmadi, 2008). Manfaat diagnosa keperawatan adalah sebagai pedoman dalam pemberian asuhan keperawatan karena menggambarkan status kesehatan (Gaffar, 1999).

c) Perencanaan Tahap perencanaan memberikan kesempatan kepada perawat, klien, keluarga dan orang terdekat klien untuk merumuskan rencana tindakan keperawatan guna mengatasi masalah yang dialami klien. Perencanaan ini merupakan suatu petunjuk tertulis yang menggambarkan secara tepat rencana tindakan keperawatan yang dilakukan terhadap klien sesuai dengan kebutuhannya berdasarkan diagnosis keperawatan. Tahap perencanaan disebut sebagai inti atau pokok dari proses keperawatan sebab perencanaan merupakan keputusan awal yang memberi arah bagi tujuan yang ingin dicapai, hal yang akan dilakukan, termasuk bagaimana, kapan, dan siapa yang akan melakukan tindakan keperawatan. Penyusunan rencana tindakan keperawatan untuk klien, keluarga dan orang terdekat perlu dilibatkan secara maksimal (Asmadi, 2008).

d) Implementasi yang merupakan komponen dari proses keperawatan adalah katagori dari perilaku keperawatan dimana tindakan yang diperlukan untuk mencapai tujuan dan hasil yang dipekirakan dari asuhan keperawatan dilakukan dan diselesaikan. Implementasi dari rencana asuhan keperawatan mengikuti komponen perencanaan dari proses keperawatan. Sedangkan di lingkungan perawatan kesehatan lainnya, implementasi mungkin dimulai secara langsung setelah pengkajian (Potter \& Perry, 2005).

e) Evaluasi Evaluasi adalah tahap akhir dari proses keperawatan yang merupakan perbandingan yang sistematis dan terencana antara hasil akhir yang teramati dan tujuan atau kriteria hasil yang dibuat pada tahap perencanaan. Evaluasi dilakukan secara berkesinambungan dengan melibatkan klien dan tenaga kesehatan lainnya. Jika hasil evaluasi menunjukkan tercapainya tujuan dan kriteria hasil, klien dapat keluar dari siklus proses keperawatan. Jika sebaliknya, klien akan masuk kembali ke dalam siklus tersebut mulai dari pengkajian ulang. Secara umum, evaluasi ditujukan untuk: 1) Melihat dan menilai kemampuan klien dalam mencapai tujuan. 2) Menentukan apakah tujuan keperawatan telah tercapai atau belum. 3) Mengkaji penyebab jika tujuan asuhan keperawatan belum tercapai 
(Asmadi, 2008).

\section{a. Asuhan Keperawatan}

Asuhan keperawatan adalah faktor penting dalam kelangsungan hidup pasien dan aspekaspek pemeliharaan, rehabilitatif dan prefentif perawatan kesehatannya. Menurut Shore, untuk sampai pada hal ini, profesi keperawatan telah mengidentifkasi proses pemecahan masalah yang "menggabungkan elemen yang paling diinginkan dari seni keperawatan dengan elemen yang paling relevan dari sistem teori, dengan menggunakan metode ilmiah".

Proses keperawatan ini diperkenalkan pada tahun 1950-an sebagai proses yang terdiri atas tiga tahap : Pengkajian, perencanaan dan evaluasi yang didasarkan pada metode ilmiah pengamatan, pengukuran, pengumpulan data dan penganalisaan temuan.

Kajian selama bertahun-tahun, penggunaan dan perbaikan telah mengarahkan perawat pada pengembangan proses keperawatan menjadi lima langkah yang konkret (pengkajian, identifikasi masalah, perencanaan, implementasi dan evaluasi) yang memberikan metode efisien tentang pengorganisasian proses berfikir untuk pembuatan keputusan klinis.

\section{b. Kepuasan Keperawatan}

Kepuasan pasien merupakan perasaan yang dimiliki pasien dan timbul sebagai hasil dari kinerja layanan kesehatan setelah pasien membandingkannya dengan apa yang diharapkan (Pohan, 2007). Hasil tersebut berupa respon dari pasien terhadap pelayanan kesehatan yang diterima secara nyata. Pelayanan kesehatan yang dimaksud dalam penelitian ini yakni pelayanan keperawatan. Pelayanan keperawatan yang diterima oleh pasien ternyata lebih buruk dari harapan pasien, maka pasien tersebut merasa tidak puas karena merasa kecewa. Apabila pelayanan keperawatan yang diterima oleh pasien ternyata sebanding dengan harapan pasien maka pasien merasa puas (senang). Kepuasan pasien adalah suatu prioritas yang akan membantu perawat dalam memberikan pelayanan keperawatan agar pasien mau berparisipasi selama perawatan.

Menurut Peter dan Olson (2000), kepuasan pelanggan adalah konsep penting dalam konsep pemasaran dan penelitian konsumen. Sudah menjadi pendapatan umum bahwa jika pelanggan merasa puas dengan suatu produk atau merek, mereka cenderung akan terus membeli dan menggunakannya serta memberitahukan orang lain tentang pengalamannya yang menyenangkan dengan produk tersebut. Jika mereka tidak dipuaskan, mereka cenderung beralih merek serta mengajukan keberatan pada produsen, pengecer, dan bahkan menceritakannya kepada pelanggan lainnya.

Menurut Kotler dan Keller (2009), kepuasan pelanggan (customer satisfaction) diartikan sebagai fungsi dari seberapa sesuainya harapan pembeli produk dengan kinerja yang dipikirkan 
pembeli atas produk tersebut. Westbrook dan Reilly juga memberikan definisi atau pengertian kepuasan pelanggan (customer satisfaction) sebagai respons emosional terhadap pengalamanpengalaman berkaitan dengan produk atau jasa tertentu yang dibeli, gerai ritel, atau bahkan pola perilaku (seperti perilaku berbelanja dan perilaku pembeli), serta pasar secara keseluruhan (dalam Tjiptono 2008).

\section{c. Klasifikasi Kepuasan}

Menurut Gerson (2002), untuk mengetahui tingkat kepuasan pelanggan dapat diklasifikasikan dalam beberapa tingkatan sebagai berikut :

1. Sangat memuaskan Diartikan sebagai ukuran subjektif hasil penilaian perasaan pasien yang menggambarkan pelayanan kesehatan sepenuhnya atau sebagian besar sesuai kebutuhan atau keinginan pasien, seperti sangat bersih (untuk prasarana), sangat ramah (untuk hubungan dengan dokter atau perawat), atau sangat cepat (untuk proses administrasi), yang seluruhnya menggambarkan tingkat kualitas pelayanan yang paling tinggi.

2. Memuaskan Diartikan sebagai ukuran subjektif hasil penilaian perasaan pasien, yang menggambarkan

pelayanan kesehatan tidak sepenuhnya atau sebagian sesuai kebutuhan atau keinginan seperti tidak terlalu bersih (untuk sarana), agak kurang cepat (proses administrasi), atau kurang ramah, yang seluruhnya ini menggambarkan tingkat kualitas yang kategori sedang.

3. Tidak memuaskan Diartikan sebagai ukuran subjektif hasil penilaian perasaan pasien rendah, yang menggambarkan pelayanan kesehatan tidak sesuai kebutuhan atau keinginan seperti tidak terlalu bersih (untuk sarana), agak lambat (untuk proses administrasi), atau tidak ramah.

4. Sangat tidak memuaskan. Diartikan sebagai ukuran subjektif hasil penilaian perasaan pasien yang rendah, menggambarkan pelayanan kesehatan tidak sesuai kebutuhan atau keinginan seperti tidak bersih (untuk sarana), lambat (untuk proses administrasi), dan tidak ramah. Seluruh hal ini menggambarkan tingkat kualitas yang kategori paling rendah.

\section{Penutup}

Pengkajian Keperawatan merupakan dasar pelaksanaan proses keperawatan. Pengkajian keperawatan dapat dimulai dengan melakukan pengumpulan data-data klien yang didapatkan dari berbagai sumber data dan teknik pengumpulan data yang berfungsi untuk mengenali dan mengidentifikasi kebutuhan dan permasalahan kesehatan yang dialami klien dan kemudian dituliskan dalam dokumentasi keperawatan. Maka dari itu, dibutuhkan perawat yang memiliki pengetahuan luas dan bertanggung jawab sehingga data yang dikumpulkan akurat dan relevan 
sesuai dengan kondisi permasalahan klien. Pengumpulan data sangat dibutuhkan dikarenakan datadata yang dikumpulkan melalui pengkajian keperawatan berperan besar dalam menentukan asuhan keperawatan klien selanjutnya.

\section{Daftar Pustaka}

1. Achmadi, Lutfiani D.L. Pondaag, L. Babakal, A. (2015). Gambaran Tingkat Pengetahuan Perawat Dalam Penerapan Standar Asuhan Keperawatan Di Ruangan Rawat Inap Interna RSUD DATOE BHINANGKANG. E-journal Keperawatan (e-kp). Vol. 3(3).

2. Anggeria, Elis. Maria. (2018). Hubungan Supervisi Dengan Pelaksanaan Asuhan Keperawatan Di Ruang Rawat Inap Lantai 10 Rumah Sakit Umum Royal Prima Medan Tahun 2017. Jurnal JUMANTIK, Vol. 3(2). 78-97.

3. Astar, F. Tamsah, H, Kadir, I. Pengaruh Pelayanan Asuhan Keperawatan Terhadap Kepuasan Pasien di Puskesma Takalala Kabupaten Soppeng. MIRAI : Journal of Management, 1(2), 33-57.

4. Budiono. (2016). Konsep Dasar Keperawatan. Jakarta : Kementerian Kesehatan Republik Indonesia.

5. Bumulo, M. I. Bidjuni, H. Bawotong, J. (2017). Pengaruh Manajemen Model Asuhan Keperawatan Profesional Tim Terhadap Kualitas Pelayanan Keperawatan di Bangsal Pria RSUD Datoe Binangkang Kabupaten Bolaang Mongondow. e-Jurnal Keperawatan, 5(2), 1-6.

6. Dinarti, Mulyanti Y. (2017). Dokumentasi Keperawatan. Jakarta : Kementerian Kesehatan Republik Indonesia.

7. Efendy, M.A. Purwandari, R. (2012). Perbedaan Tingkat Kualitas Dokumentasi Proses Keperawatan Sebelum dan Sesudah Penerapan NANDA-1, NIC dan NOC. Jurnal Keperawatan Soedirman. Vol. 7(2). 67-77.

8. Simamora, R. H. (2019). Development of Guidelines for Applying appropriate Patient Identification to Achieve Patient Safety Goal INC2019 12th International Nursing Conference. 2019.10455 - 455 (1 pages) UCI(KEPA) : I410-ECN-0101-2019-512-001224337

9. Simamora. R. H. (2008) The correlation of ward chief's giving direction and command and the performance of on-duty nurses at Jember dr. Subandi general hospital inpatient wards. jurnal Administrasi dan Kebijakan Kesehatan, (https://fkm.unair.ac.id/jurnal-administr)

10. Susanto, Rachmat. (2010). Penerapan Standar Proses Keperawatan di Puskesmas Rawat Inap Cilacap. Jurnal Keperawatan Soedirman, 5(2), 80-84.

11. Tokan, P. K. Sekunda, M. S. (2020). Penerapan Format Baru Pendokumentasian Asuhan Keperawatan di Poli Rawat Jalan Puskesmas. Jurnal Kesehatan Primer, 5(1), 61-69.

12. Yanti, R. I. Warsito, B. E. (2013). Hubungan Karakteristik Perawat, Motivasi, dan Supervisi dengan Kualitas Dokumentasi Proses Asuhan Keperawatan. Jurnal Managemen Keperawatan, 1(2), $107-$ 114. 